\title{
Developmental Origins of $\beta$-Cell Failure in Type 2 Diabetes: The Role of Epigenetic Mechanisms
}

\author{
REBECCA A. SIMMONS \\ Department of Pediatrics Children's Hospital Philadelphia and University of Pennsylvania, Philadelphia, Pennsylvania 19104
}

\begin{abstract}
Intrauterine growth retardation (IUGR) has been linked to later development of type 2 diabetes in adulthood. An abnormal metabolic intrauterine milieu affects the development of the fetus by permanently modifying gene expression of susceptible cells. Altered gene expression persists after birth, suggesting that an epigenetic mechanism may be responsible for changes in transcription. Uteroplacental insufficiency (IUGR) is associated with hypomethylation and hyperacetylation of genomic DNA in brain and liver of IUGR fetal and juvenile rats. These findings are associated with zinc deficiency that often accompanies fetal growth retardation. Studies in the IUGR rat also demonstrate that an abnormal intrauterine environment induces epigenetic modifications of key genes regulating $\beta$-cell development and experiments directly link chromatin remodeling to suppression of transcription. Dietary protein restriction of pregnant rats causes fetal growth retardation and is associated with hypomethylation of the glucocorticoid receptor (GR) and PPAR $\gamma$ genes in liver of the offspring. It is postulated that these epigenetic changes result in the observed increase in gene expression of GR and $\operatorname{PPAR} \gamma$. Future research will be directed at elucidating the mechanisms underlying epigenetic modifications in offspring. (Pediatr Res 61: 64R-67R, 2007)
\end{abstract}

A $\mathrm{n}$ adverse intrauterine milieu impacts the development of the fetus by modifying gene expression in both pluripotential cells or terminally differentiated, poorly replicating cells. The long-range effects on the offspring (into adulthood) depend upon the cells undergoing differentiation, proliferation, and/or functional maturation at the time of the disturbance in maternal fuel economy. Permanent alterations to the phenotype of the offspring suggest that fetal growth retardation is associated with stable changes in gene expression. In this article, a general review of epigenetics will be provided and the possible causal role of chromatin remodeling in the development of type 2 diabetes will be discussed.

\section{CHROMATIN STRUCTURE, DNA METHYLATION, AND GENE EXPRESSION}

Epigenetic modifications of the genome provide a mechanism that allows the stable propagation of gene activity states from one generation of cells to the next. Excellent reviews on this topic appear frequently, reflecting the rapid advances of

Received November 14, 2006; accepted December 31, 2006.

Correspondence: Rebecca Simmons, M.D., University of Pennsylvania, BRB II/III, Rm 1308, 421 Curie Blvd., Philadelphia, PA 19104; e-mail: rsimmons@mail.med.upenn.edu

RS is supported by National Institutes of Health grant numbers DK55704 and AG20898.

DOI: $10.1203 / p d r .0 b 013 e 3180457623$ knowledge in the field (1-4). Epigenetic states can be modified by environmental factors, which may contribute to the development of abnormal phenotypes. There are at least two distinct classes of epigenetic information that can be inherited with chromosomes. One class of epigenetic control of gene expression involves changes in chromatin proteins, usually involving modifications of histone tails. In eukaryotes, DNA is assembled with histones to form the nucleosome, in which DNA is wrapped approximately two turns around an octameric complex composed of two molecules of each of the four histones $\mathrm{H} 2 \mathrm{~A}, \mathrm{H} 2 \mathrm{~B}, \mathrm{H} 3$, and $\mathrm{H} 4$. The amino termini of histones can be modified by acetylation, methylation, sumoylation, phosphorylation, glycosylation, and ADP ribosylation. The most common modifications involve acetylation and methylation of lysine residues in the amino termini of $\mathrm{H} 3$ and H4. Increased acetylation induces transcription activation, whereas decreased acetylation usually induces transcription repression. Methylation of histones is associated with both transcription repression and activation. Moreover, lysine residues can be mono-, di-, or trimethylated in vivo, thus providing an additional mechanism of regulation. Trimethylation of lysine residues is only found at active genes, whereas dimethylation occurs in both active and inactive chromatin. Several chromatin modification states are mutually reinforcing. For example, methylation of lysine 9 on histone H3 can promote DNA methylation, and $\mathrm{CpG}$ methylation (see below) stimulates methylation of lysine 9 on histone H3 (5). Thus, chromatin modifications induced by adverse stimuli are selfreinforcing and can propagate.

The second class of epigenetic regulation is DNA methylation, in which a cytosine base is modified by a DNA methyltransferase at the $\mathrm{C} 5$ position of cytosine, a reaction that is carried out by various members of a single family of enzymes. Approximately $70 \%$ of $\mathrm{CpG}$ dinucleotides in human DNA are constitutively methylated, whereas most of the unmethylated $\mathrm{CpGs}$ are located in $\mathrm{CpG}$ islands. $\mathrm{CpG}$ islands are CG-rich sequences located near coding sequences and serve as promoters for the associated genes. Approximately half of mammalian genes have $\mathrm{CpG}$ islands. Methylation of $\mathrm{CpG}$ sites is also maintained by DNA methyltransferases. DNA methylation is commonly associated with gene silencing and contributes to X-chromosomal inactivation, genomic imprinting, and transcriptional regulation of tissue-specific genes during

Abbreviations: HDAC1, histone deacetylase 1; IUGR, intrauterine growth retardation 
cellular differentiation (6-8). The methylation status of $\mathrm{CpG}$ islands within promoter sequences works as an essential regulatory element by modifying the binding affinity of transcription factors to DNA binding sites.

Most CpG islands remain unmethylated in normal cells, however, under some circumstances such as cancer (9-14) and oxidative stress (see below), they can become methylated de novo. This aberrant methylation is accompanied by local changes in histone modification and chromatin structure, such that the $\mathrm{CpG}$ island and its embedded promoter take on a repressed conformation that is incompatible with gene transcription. It is not known why particular $\mathrm{CpG}$ islands are susceptible to aberrant methylation. A recent study by Feltus et al. (15) suggests that there is a "sequence signature associated with aberrant methylation." Of major significance to type 2 diabetes is their finding that $P d x-1$, a pancreatic homeobox transcription factor, was one of only $15 \mathrm{CpG}$ genes (a total of 1749 genes with $\mathrm{CpG}$ islands were examined) that were methylation susceptible under conditions of increased methylation induced by over-expression of a DNA methyl transferase.

\section{NUTRITIONAL STATUS AND EPIGENETIC MODIFICATIONS}

The metabolic or nutritional state of the organism directly influence epigenetic modifications and the process of chromatin remodeling depends upon a number of products derived from intermediary metabolism such as S-adenosyl methionine (SAM), acetyl CoA, and nicotinamide adenine dinucleotide $\left(\mathrm{NAD}^{+}\right)$.

A role for environmental regulation of epigenetic phenomena has been established by experiments performed in agouti mice $(16,17)$. In this animal, an endogenous retrovirus-like transposon sequence is inserted close to the gene coding for the Agouti protein. An unmethylated retrotransposon promoter overrides the agouti promoter, resulting in ectopic agouti expression and a yellow coat. A methylated retrotransposon cannot do this, resulting in a wild-type agouti coat. Yellow mothers produce more yellow offspring than agouti mothers, even when all the mice are genetically identical. These mice have yellow hair, obesity, hyperinsulinemia, diabetes, increased somatic growth, and increased susceptibility to hyperplasia and tumorigenesis (18). Wolff et al. (16) have investigated whether maternal diet can alter the phenotype of the $\mathrm{A}^{\mathrm{IAP}}$ mice. They found that when pregnant females are fed a diet supplemented with methyl donors, a larger proportion of offspring have a wild-type coat color as compared with the offspring of mothers fed a standard diet. These results suggest that an environmental stimulus early in life can change the stable expression of genes and affect the phenotype of the adult.

\section{CHROMATIN REMODELING AND DISEASE STATES}

Homeobox genes are frequently down-regulated in association with aberrant methylation in human cancer cells (10) and the HOX gene clusters are a hotspot of de novo methylation in lung cancers (11). In addition to targeted DNA methylation changes in response to external stimuli, random DNA methylation changes have been shown to occur during aging of organisms in several tissue types $(12,13)$.

Hypermethylation of specific genes has also been observed in tissues of aging individuals $(13,19)$. Type 2 diabetes is strongly age-related, as its incidence is increased in older populations, and the metabolic profile of individual patients deteriorates over time. DNA methylation errors that accumulate with increasing age could provide one explanation, and this may be related to oxidative stress.

Reactive oxygen species can also lead to alterations in DNA methylation without changing the DNA base sequence (20). Such changes in DNA methylation patterns have been shown to affect the expression of multiple genes (20). Replacement of guanine with the oxygen radical adduct 8-hydroxyguanine profoundly alters methylation of adjacent cytosines (20). Histones, because of their abundant lysine residues, are also very susceptible to oxidative stress (21-23).

\section{EPIGENETIC REGULATION OF GENE EXPRESSION IN FETAL GROWTH RETARDATION}

A number of studies have suggested that uteroplacental insufficiency, the most common cause of intrauterine growth retardation in the developed world, induces epigenetic modifications in the offspring (24-26). Fetal growth retardation is induced by bilateral uterine artery ligation in the pregnant rat (27). The unique feature of this model is its ability to induce diabetes in adult animals at approximately $15-26$ wk of age with underlying $\beta$-cell secretory defects and insulin resistance, the salient features of most forms of type 2 diabetes in the human $(27,28)$. Genome-wide DNA hypomethylation has been found in postnatal IUGR liver and was associated with an increase in total $\mathrm{H} 3$ acetylation (24). Acetylation of histone $\mathrm{H} 3$ and acetylation of H3 lysine-9 (H3/K9), lysine-14 (H3/ $\mathrm{K} 14)$, and lysine-18 (H3/K18) was increased at the promoters of PGC-1 and CPTI, respectively, in IUGR liver (26). At d 21 of life, the neonatal pattern of $\mathrm{H} 3$ hyperacetylation persisted only in the IUGR males. Whether hyperacetylation at these sites actually causes increased transcription of PGC- 1 or CPT1 and how these findings relate to a phenotype in the offspring remains to be determined.

\section{CHROMATIN REMODELING IN THE $\beta$-CELL OF IUGR RATS}

Studies in the IUGR rat also demonstrate that fetal growth retardation induces epigenetic modifications of key genes regulating $\beta$-cell development (28a). $P d x-1$ is a homeodomain-containing transcription factor that plays a critical role in the early development of both endocrine and exocrine pancreas, and then in the later differentiation and function of the $\beta$ cell. As early as $24 \mathrm{~h}$ after the onset of growth retardation, $P d x-1$ mRNA levels are reduced by more than $50 \%$ in IUGR fetal rats. Suppression of $P d x-1$ expression persists after birth and progressively declines in the IUGR animal, implicating an epigenetic mechanism. 
The proximal promoter of $P d x-1$ is obligate for transcription of the gene, and the histones $\mathrm{H} 3$ and $\mathrm{H} 4$ are heavily acetylated in normal $\beta$-cells (29). However, in islets of IUGR animals, $\mathrm{H} 3$ and $\mathrm{H} 4$ in this region of the $P d x-1$ promoter are deacetylated. Histone deacetylation is catalyzed by HDAC, and HDAC1 is strongly associated with the proximal $P d x-1$ promoter in IUGR $\beta$-cells. Reversal of deacetylation by an HDAC inhibitor normalizes $P d x-1$ expression in islets of IUGR animals, demonstrating that histone deacetylation contributes to the observed $P d x-1$ transcription suppression.

Unlike acetylation, histone $\mathrm{H} 3$ methylation can be equally associated with either transcriptional activation or repression. Methylation of the lysine residue Lys4 H3 (H3-K4) correlates with activation of gene expression, whereas H3Lys9 (H3-K9) methylation is involved in the establishment and maintenance of silent heterochromatin regions. Lysine methylation is catalyzed by the action of histone methyltransferases (SET7/9), which demonstrate a high degree of specificity for H3-K4. There is a loss of binding of SET7/9 to the proximal promoter of $P d x-1$ in $\beta$-cells from IUGR animals, which results in a marked reduction of methylation of $\mathrm{H} 3 \mathrm{~K} 4$ in this region of $P d x-1$. These observations demonstrate that the level of $\mathrm{H} 3$ acetylation is linked to the degree of $\mathrm{H} 3 \mathrm{~K} 4$ methylation.

Transcriptional repression is also facilitated by methyl-CpG binding proteins that bind to promoter-proximal methylated DNA sequences, thereby maintaining the condensed nucleosome structure (30). However, one methyl-CpG-binding domain protein-MeCP2 also mediates transcription repression through histone deacetylation (31-33). MeCP2 contains a transcriptional repression domain that functions by recruitment of the co-repressor Sin3A, a histone deacetylase (3133 ), and a histone 3 lysine 9 methyltransferase (Suv39h) $(34,35)$. MeCP2 binding is seen in IUGR fetal pancreas as early as $24 \mathrm{~h}$ after uterine artery ligation. Association of $\mathrm{MeCP} 2$ with the proximal promoter of $P d x-1$ precipitates Sin3A binding at $d 1$ of life in IUGR islets. The repressor complex consisting of MeCP2, Sin3A, HDAC1, and Suv39h induce $\mathrm{H} 3$ deacetylation and methylation of $\mathrm{H} 3 \mathrm{~K} 9$. Thus, a cascade of epigenetic events is triggered by IUGR, resulting in permanent suppression of Pdx-1 expression. The sequence of epigenetic events (Fig. 1) that occurs in IUGR islets leading to suppression of $P d x-1$ transcription appears to be the following: $\mathrm{MeCP} 2$ binds to methylated DNA in the $\mathrm{CpG}$ island at the $P d x-1$ promoter. This results in recruitment of a repressor complex, which catalyzes the deacetylation of $\mathrm{H} 3$ and methylation of H3K9, respectively. Deacetylation of H3 in turn promotes the loss of H3K4 methylation, further suppressing $P d x-1$ transcription. As the IUGR animals age, DNA methylation of the $\mathrm{CpG}$ island progresses, thereby locking in the silencing of $P d x-1$ expression.

How do these events lead to diabetes? Targeted homozygous disruption of $P d x-1$ in mice results in pancreatic agenesis (36), and homozygous mutations yield a similar phenotype in humans (37). Milder reductions in $P d x$-1 protein levels, as occurs in the $P d x+/-$ mice, allow for the development of a normal mass of $\beta$ cells (38), but result in the impairment of several events in glucose-stimulated insulin secretion (39). These results indicate that $P d x-1$ plays a critical role, distinct

\section{Pdx-1}
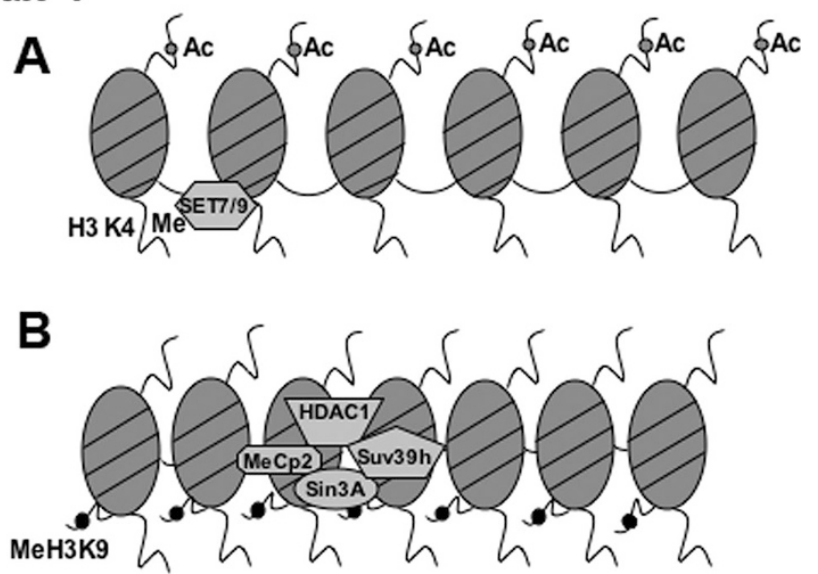

Figure 1. Schematic of histone acetylation and methylation of the proximal promoter of Pdx-1. (A) H3 is heavily acetylated and H3K4 is methylated in islets from control animals. H3K4 methylation is catalyzed by SET7/9. (B) Acetylation of $\mathrm{H} 3$ and methylation of $\mathrm{H} 3 \mathrm{~K} 4$ of Pdx-1 are lost in IUGR islets.

from its developmental role, in the normal function of $\beta$ cells (40). This may be the reason that humans with heterozygous missense mutations in $P d x$-1 exhibit early and late onset forms of type 2 diabetes $(40,41)$.

\section{SUMMARY}

The studies described above clearly show that environmental effects can induce epigenetic alterations. Much of the recent progress in understanding epigenetic phenomena is directly attributable to technologies that allow researchers to pinpoint the genomic location of proteins that package and regulate access to the DNA. The advent of DNA microarrays and inexpensive DNA sequencing has allowed many of those technologies to be applied to the whole genome. It is possible that epigenetic profiling of $\mathrm{CpG}$ islands in the human genome can be used as a tool to identify genomic loci that are susceptible to DNA methylation. Aberrant hypermethylation may be then be used as a biomarker for disease (42-45).

The genome-wide mapping of histone modifications by ChIP-chip has led to important insights regarding the mechanism of transcriptional and epigenetic memory, and how different chromatin states are propagated through the genome in yeast (45). To date, there is only one published report of a genome-wide, high-resolution ChIP-chip study in mammalian cells (46). In the near future, it is likely that technologies will be developed that will allow genome-wide epigenetics studies, especially applied to the limited numbers of cells that can be isolated to a high degree of purity by techniques such as laser capture microscopy.

\section{REFERENCES}

1. Bannister AJ, Kouzarides T 2005 Reversing histone methylation. Nature 436:11031106

2. Bernstein E, Allis CD 2005 RNA meets chromatin. Genes Dev 19:1635-1655

3. Mellor J 2005 The dynamics of chromatin remodeling at promoters. Mol Cell 19:147-157

4. Sproul D, Gilbert N, Bickmore WA 2005 The role of chromatin structure in regulating the expression of clustered genes. Nat Rev Genet 6:775-781

5. Schubeler D, Lorincz MC, Cimbora DM, Telling A, Feng YQ, Bouhassira EE, Groudine M 2000 Genomic targeting of methylated DNA: influence of methylation 
on transcription, replication, chromatin structure, and histone acetylation. Mol Cell Biol 20:9103-9112

6. Costello JF, Fruhwald MC, Smiraglia DJ, Rush LJ, Robertson GP, Gao X, Wright FA, Feramisco JD, Peltomaki P, Lang JC, Schuller DE, Yu L, Bloomfield CD, Caligiuri MA, Yates A, Nishikawa R, Su Huang H, Petrelli NJ, Zhang X, O’Dorisio MS, Held WA, Cavenee WK, Plass C 2000 Aberrant CpG-island methylation has non-random and tumour-type-specific patterns. Nat Genet 24:132-138

7. Galm O, Yoshikawa H, Esteller M, Osieka R, Herman JG 2003 SOCS-1, a negative regulator of cytokine signaling, is frequently silenced by methylation in multiple myeloma. Blood 101:2784-2788

8. Yoshikawa H, Matsubara K, Qian GS, Jackson P, Groopman JD, Manning JE, Harris CC, Herman JG 2001 SOCS-1, a negative regulator of the JAK/STAT pathway, is silenced by methylation in human hepatocellular carcinoma and shows growthsuppression activity. Nat Genet 28:29-35

9. He B, You L, Uematsu K, Zang K, Xu Z, Lee AY, Costello JF, McCormick F, Jablons DM 2003 SOCS-3 is frequently silenced by hypermethylation and suppresses cell growth in human lung cancer. Proc Natl Acad Sci U S A 100:1413314138

10. Yoshida H, Broaddus R, Cheng W, Xie S, Naora H 2006 Deregulation of the HOXA10 homeobox gene in endometrial carcinoma: role in epithelial-mesenchymal transition. Cancer Res 66:889-897

11. Shiraishi M, Sekiguchi A, Oates AJ, Terry MJ, Miyamoto Y 2002 HOX gene clusters are hotspots of de novo methylation in $\mathrm{CpG}$ islands of human lung adenocarcinomas. Oncogene 21:3659-3663

12. Kim JY, Siegmund KD, Tavare S, Shibata D 2005 Age-related human small intestine methylation: evidence for stem cell niches. BMC Med 3:10-15

13. So K, Tamura G, Honda T, Homma N, Waki T, Togawa N, Nishizuka S, Motoyama T 2006 Multiple tumor suppressor genes are increasingly methylated with age in non-neoplastic gastric epithelia. Cancer Sci 97:1155-1158

14. Takahashi T, Shigematsu H, Shivapurkar N, Reddy J, Zheng Y, Feng Z, Suzuki M, Nomura M, Augustus M, Yin J, Meltzer SJ, Gazdar A 2006 Aberrant promoter methylation of multiple genes during multistep pathogenesis of colorectal cancers. Int J Cancer 118:924-931

15. Feltus FA, Lee EK, Costello JF, Plass C, Vertino PM 2003 Predicting aberrant CpG island methylation. Proc Natl Acad Sci U S A 100:12253-12258

16. Cooney CA, Dave AA, Wolff GL 2002 Maternal methyl supplements in mice affect epigenetic variation and DNA methylation of offspring. J Nutr 132:2393S-2400S.

17. Wolff GL 2003 Regulation of yellow pigment formation in mice: a historical perspective. Pigment Cell Res 16:2-15

18. Miltenberger RJ, Mynatt RL, Wilkinson JE, Woychik RP 1997 The role of the agouti gene in the yellow obese syndrome. J Nutr 127:1902S-1907S

19. Choi SW, Friso S, Keyes MK, Mason JB 2005 Folate supplementation increases genomic DNA methylation in the liver of elder rats. Br J Nutr 93:31-35

20. Cerda S, Weitzman SA 1997 Influence of oxygen radical injury on DNA methylation. Mutat Res 386:141-152

21. Drake J, Petroze R, Castegna A, Ding Q, Keller JN, Markesbery WR, Lovell MA, Butterfield DA 2004 4-Hydroxynonenal oxidatively modifies histones: implications for Alzheimer's disease. Neurosci Lett 356:155-158

22. Gilmour PS, Rahman I, Donaldson K, MacNee W 2003 Histone acetylation regulates epithelial IL-8 release mediated by oxidative stress from environmental particles. Am J Physiol Lung Cell Mol Physiol 284:L533-L540

23. Rahman I, Gilmour PS, Jimenez LA, MacNee W 2002 Oxidative stress and TNF-alpha induce histone acetylation and NF-kappaB/AP-1 activation in alveolar epithelial cells: potential mechanism in gene transcription in lung inflammation. Mol Cell Biochem 234- 235:239-248

24. MacLennan NK, James SJ, Melnyk S, Piroozi A, Jernigan S, Hsu JL, Janke SM, Pham TD, Lane RH 2004 Uteroplacental insufficiency alters DNA methylation, one-carbon metabolism, and histone acetylation in IUGR rats. Physiol Genomics $18: 43-50$

25. Pham TD, MacLennan NK, Chiu CT, Laksana GS, Hsu JL, Lane RH 2003 Uteroplacental insufficiency increases apoptosis and alters p53 gene methylation in the full-term IUGR rat kidney. Am J Physiol Regul Integr Comp Physiol 285:R962R970
26. Fu Q, McKnight RA, Yu X, Wang L, Callaway CW, Lane RH 2004 Uteroplacental insufficiency induces site-specific changes in histone $\mathrm{H} 3$ covalent modifications and affects DNA-histone H3 positioning in day 0 IUGR rat liver. Physiol Genomics 20:108-116

27. Simmons RA, Templeton L, Gertz S, Niu H 2001 Intrauterine growth retardation leads to type II diabetes in adulthood in the rat. Diabetes 50:2279-2286

28. Stoffers DA, Desai BM, DeLeon DD, Simmons RA 2003 Neonatal exendin-4 prevents the development of diabetes in the intrauterine growth retarded rat. Diabetes 52:734-740

28a.Park J, Suponitsky-Kroyter I, Niu H, Simmons RA 2006 Repressor complex silences Pdx-1 in islets of growth retarded rats. Diabetes 55:1589

29. Gerrish K, Van Velkinburgh JC, Stein R 2004 Conserved transcriptional regulatory domains of the pdx-1 gene. Mol Endocrinol 18:533-548

30. Georgel PT, Horowitz-Scherer A, Adkins N, Woodcock CL, Wade PA, Hansen JC 2003 Chromatin compaction by human MeCP2. J Biol Chem 278:32181-32185

31. Nan X, Campoy FJ, Bird A 1997 MeCP2 is a transcriptional repressor with abundant binding sites in genomic chromatin. Cell 88:471-481

32. Jones PL, Veenstra GJ, Wade PA, Vermaak D, Kass SU, Landsberger N, Strouboulis J, Wolffe AP 1998 Methylated DNA and MeCP2 recruit histone deacetylase to repress transcription. Nat Genet 19:187-191

33. Nan X, Ng HH, Johnson CA, Laherty CD, Turner BM, Eisenman RN, Bird A 1998 Transcriptional repression by the methyl-CpG-binding protein $\mathrm{MeCP} 2$ involves a histone adeacetylase complex. Nature 393:386-389

34. Fuks F, Burgers WA, Brehm A, Hugh-Davies L, Kouzarides T 2000 DNA methyltransferase Dnmt1 associates with histone deacetylase activity. Nat Genet 24:88-91

35. Martinowich K, Hattori D, Wu H, Fouse S, He F, Hu Y, Fan G, Sun YE 2003 DNA methylation-related chromatin remodeling in activity dependent Bdnf gene regulation. Science 302:890-893

36. Jonsson J, Carlsson L, Edlund T, Edlund H 1994 Insulin-promoter-factor 1 is required for pancreas development in mice. Nature 371:606-609

37. Stoffers DA, Zinkin NT, Stanojevic V, Clarke WL, Habener JF 1997 Pancreatic agenesis attributable to a single nucleotide deletion in the human IPF1 coding region. Nat Genet 15:106-110

38. Dutta S, Bonner-Weir S, Montminy M, Wright C 1998 Regulatory factor linked to late-onset diabetes? Nature 392:560

39. Brissova M, Shiota M, Nicholson WE, Gannon M, Knobel SM, Piston DW, Wrigh CV, Powers AC 2002 Reduction in pancreatic transcription factor Pdx-1 impairs glucose-stimulated insulin secretion. J Biol Chem 277:11225-11232

40. Hani EH, Stoffers DA, Chevre JC, Durand E, Stanojevic V, Dina C, Habener JF, Froguel P 1999 Defective mutations in the insulin promoter factor-1 (IPF-1) gene in late-onset type 2 diabetes mellitus. J Clin Invest 104:R41-R48

41. Stoffers DA, Ferrer J, Clarke WL, Habener JF 1997 Early-onset type-II diabetes mellitus (MODY4) linked to IPF-1. Nat Genet 17:138-139

42. Gebhard C, Schwarzfischer L, Pham TH, Schilling E, Klug M, Andreesen R, Rehli M 2006 Genome-wide profiling of $\mathrm{CpG}$ methylation identifies novel targets of aberrant hypermethylation in myeloid leukemia. Cancer Res 66:6118-28

43. Ordway JM, Bedell JA, Citek RW, Nunberg A, Garrido A, Kendall R, Stevens JR, Cao D, Doerge RW, Korshunova Y, Holemon H, McPherson JD, Lakey N, Leon J, Martienssen RA, Jeddeloh JA 2006 Comprehensive DNA methylation profiling in a human cancer genome identifies novel epigenetic targets. Carcinogenesis 27:24092423

44. Mori Y, Cai K, Cheng Y, Wang S, Paun B, Hamilton JP, Jin Z, Sato F, Berki AT, Kan T, Ito T, Mantzur C, Abraham JM, Meltzer SJ 2006 A genome-wide search identifies epigenetic silencing of somatostatin, tachykinin-1, and 5 other genes in colon cancer. Gastroenterology 131:797-808

45. Lieb JD, Beck S, Bulyk ML, Farnham P, Hattori N, Henikoff S, Liu XS, Okumura K, Shiota K, Ushijima T, Greally JM 2006 Applying whole-genome studies of epigenetic regulation to study human disease. Cytogenet Genome Res 114:1-15

46. Kim TH, Barrera LO, Zheng M, Qu C, Singer MA, Richmond TA, Wu Y, Green RD, Ren B 2005 A high-resolution map of active promoters in the human genome. Nature 436:876-880 